\title{
Youth Non-Conformism Throughout the 1920s: Main Types and Manifestation Forms
}

\author{
Roman V. Rybakov* \\ Omsk State Technical University \\ 11 Mira, Omsk, 644050, Russia
}

Received 17.05.2013, received in revised form 18.01.2014, accepted 24.02.2015

The Article describes the study of youth throughout the 1920s with use the theory of non-conformism. According to the author, youth movement of the considered period was more difficult than soviet historiography has presented. The peculiarity of youth movement in the first years the Soviet power was a growth of protest mood or non-conformism. The author characterized the main forms and nonconformism types among young generation. Their analysis significantly enriches available knowledge about youngsters of the 1920 s.

Keywords: youth, youth policy, youth organizations, Komsomol, youth non-conformism, ethnic minorities, opposition, modernization.

The work was supported by the Russian Foundation for Basic Research, project 15-06-05864a.

DOI: 10.17516/1997-1370-2015-8-9-1965-1972.

Research area: history.

\section{Introduction}

The study of Soviet youth during the first decades of the XX century comprises a lot of unknown despite a large number of works of all previous period. The problem of youth nonconformism (its reasons and manifestations) is the least investigated matter. For a long time the study of youth who didn't share the belief in communist ideals as well as those who for other reasons could not take place in the Komsomol was prevented by ideology, weak informational content of available scientific materials and inaccessibility of the documents in archives of security service. As a result, there is a situation when the past of Soviet youth is substituted by
Komsomol history. In fact, we know the history of the great victories and achievements, but existence of multi-variant youth movement is hidden for us. Unrealized possibility of creation the youth organizations on another social, cultural and even ideological platforms requires a comprehensive study.

The Soviet historiography has not denied existence of oppositional youth; however, study of this group specifically wasn't carried out. Alternative organizations were mentioned seldom, but always in a negative light, the everyday life of youth also did not interest researchers (Bahareva, Lejkin, 1990). The modern scientists try to depart from Komsomol

(C) Siberian Federal University. All rights reserved

* Corresponding author E-mail address: roman-rybakov@mail.ru 
subject through the expansion of object and subject of researches including in investigation new historical sources. The significant contribution to studying youth movement was made by the "Center of historical researches of Institute of basic and applied researches Moscow State University" (I. Ilyinsky, V. Lukov, M. Mukhamedzhanov, B. Ruchkin, V. Krivoruchenko and others). Scientific work of Moscow researchers was continued by regional scientists. The discursive-pragmatic concepts have emerged in different regions of the country showing the fundamentally different approaches to analysis of youth movement in the Soviet Russia. In the context of youth issues socialpsychological, organizational, cultural, national aspects are considered today. Among the Siberian scientists it should be noted V. Isaev. The author investigates conditions and forms of young people socialization, material and living conditions also cultural development (Isaev, 2003). By now, a lot of works have emerged in foreign historiography devoted to the study of Soviet youth. For example, research by Matthias Neumann. Based on extensive archival research and building upon recent research on Soviet youth, the monograph broadens our understanding of the social and political dimension of Komsomol membership during the momentous period 1917-1932 (Neumann, 2011). For the first time researchers have turned to the study of alternative organizations. However, it should be recognized, that today in this direction very little has been done.

\section{Theoretical framework}

The primary focus of this article is to show that the youth movement of the 1920s was more difficult than it usually represents. Research is based on achievements of a modern historiography, new methodological approaches and sources. It is important to give the characteristic the most part of the Soviet youth which for various reasons didn't find possible the existence within the communistic union of youth in the conditions of the Soviet modernization during the period of the 1920s. It is necessary to analyze the main reasons, types and non-conformism manifestations in the youth environment, and also to establish their conditionality of social economic and political contradictions of Soviet Russia. Nevertheless, it should be noted that it is impossible to fully illuminate the non-conformism views of young people without the analysis of some tendencies in the development of the Komsomol movement in the region in view of its problems and conflicts. The study is based on the theory of non-conformism which today is actively being developed and used in the Russian and foreign philosophy and social psychology. Non-conformism is the desire of the individual to counteract any imposed on him a psychological pressure by defending own position, acting in the opposite way which is being imposed by other people in spite of the existing rules and social norms. Manifestations of non-conformism are dissent, rebellion and desire to hold always a special individual position (Davletchina, 2005: 56).

The author's position is that the nonconformism cannot be regarded as only a negative phenomenon. Non-conformism in education, culture, art and science often leads to a breakthrough, discovery, masterpiece, progress. At the same time the radical non-conformism which is manifested in violence, cruelty, aggression, nationalism is a destructive element. It seems that the theory of non-conformism can be used for the characteristic the youth movement in historical retrospective of the 1920 s during the beginning of mass propaganda and agitation, impact of the state (authorities) which had the opposite effect of protest and disagreement with the official political and cultural orthodoxy. The Siberia was selected as territorial framework 
of the study, because special socio-economic, political, ethnic-religious conditions in the region was supporting a protest mood among the local residents in respect of the conducted policy of the Bolsheviks. Young people were approximately $1 / 4$ of the population could not remain indifferent to these processes. The proposed approach allows examining the youth movement of the 1920s with the position of coherence social, political, moral and economic contradictions of Soviet modernization.

We should distinguish between two main lines of non-conformism in the youth environment in the analyzed period: Komsomol non-conformism which demonstrated the internal differences and trends in the organization, as well as non-conformism of youngsters who not sympathized with main Communist ideas, existed in isolation, separately or integrated in any alternative organizations. It is important that such directions were characterized by both the passive non-conformism expressed in non-obedience and ideological resistance and the radical nonconformism which differed by actions of a violent nature or extremism (Isaev, 2002).

\section{Discussion}

The firstdecade of the Bolsheviks government is a unique time a struggle for the various models of the life of society. Totalitarianism approval was not preordained fatal: in the country had been a chance for realization of alternative socioeconomic and political development. The state was experienced by serious political, economic and national problems which were amplified by unstable international situation. The youth became a direct participant in complex processes of institutional development in conditions of actual diversity of the institutional-political, socio-cultural, ideological and other forms. That of course influenced on its integration and selforganization. Nevertheless, the scientists have not yet analyzed the factors of divergence influencing on the youth movement which were expressed not only in existence along with the Komsomol the other associations of young people, but also in the formation of non-conformist attitudes inside the Komsomol and in the development of youth extremism.

The main task of Soviet state in the 1920s was to find effective ways to overcome the national crisis. The search for models of the Soviet society development was held in the permanent inner-party struggle conditions. The Komsomol which was founded with the approval and active support by the Bolshevik party became an involuntary participant and a witness of the confrontation in the party. However, the paradox of situation lies in a fact that being in the 1920s strong enough appendage of the party most of young Communists were far from politics and those principal issues which split the party. At the same time this does not mean that there were no contradictions in the Komsomol; on the contrary, there were serious differences in objectives and tasks of youth organizations, not immediately and not everywhere unions have become faithful helpers the party sometimes demonstrated complete independence.

We believe that inside Komsomol nonconformism is possible to distinguish several levels: the lower level was a disagreement ordinary member with the aims and main directions of the work in the Union what was reflected in way out from its staff. Up to now the historical science has not conducted a comprehensive analysis of the reasons for such action. However, the mass abandonment among the youth in 1921 has put on the brink of catastrophe the Komsomol existence in Siberia. Voluntary going out from the organization was due to different reasons. For many young people the Komsomol was not the organization which they dreamed of. If on the first stage the Komsomol differed little from 
other organizations then very soon the passion to cultural and educational activities was recognized as a mistake. Discipline was intensified, the main occupation became mastering of political literacy. Youngsters have learned that they must become volunteers on the front, take part in the community work day, collect means to help the starving, take part in campaign for voluntary return of rural surplus. To refuse from the traditional village leisure - evening merry-making with an accordion, dances and drinking was even more difficult. The economic policy implemented in village forced the young generation to doubt in correctness the actions of power. Some young communists left organization after their parents had not allowed joining the Komsomol; others tore contact with the Komsomol because of a difficult pecuniary situation, a small allowance or sometimes because of the marriage. So, the members of the youth organization in the Omsk region in the number of 14 persons left the Union after marriage saying: «it is better to go for a drive with wife on sledges».

The large-scale reduction of Komsomol organizations began in the spring 1921. The Komsomol membership rapidly reduced from about 480,000 to around 250,000 by June 1921 (Kenez, 1985: 69). In Siberia the decline was greater than average in the country: from 40,000 to 30,000 by July 1921 and to 20,000 by May $1922^{1}$. The numerical reduction of the organizations should be considered as a crisis of confidence of rural youth to the Communist ideology.

The second level of non-conformism should be determined as opposition some groups of young people in different level inside the Komsomol. The first Komsomol organizations in Siberia began to emerge at the end of 1919. Their active work began immediately after the territory was liberated from the forces of Admiral Kolchak. Local youth organizations were created under the leadership of party committees and representatives of political departments of the Red Army, much less on the youth initiative. Sometimes random people were appointed on posts without the appropriate abilities, skills and knowledge. Therefore, if the work of the organizations was not satisfactory they had been re-elected. As a rule, in the reports on such occasion it was reported that after the re-election the work in the cell perked up and went in the right direction, and has never been mentioned about the fate of those people who have lost the jobs. In most organizations really «change of power» took place peacefully, but there were also cells where the internal struggle lasted quite a long time up to the intervention of higher authorities and party. Difficult situation was in the Altai guberniya (province). The worker of the Altai regional Committee Mungalov A. pointed out that inside the Altai team a tension was considerable by the spring of 1921 . Some youngsters showed dissatisfaction by the line of the local Committee aimed at the expansion of the staff and intensification mandatory form of work. Biysk district Committee (part of Altai regional Committee) headed by the Secretary Hudoleev turned into a military headquarters, and all members of the Komsomol were «chekists». Within the team were formed two groups: one under the guidance of the secretary Zinchenko, another oppositional under the leadership of Strobykin and Arsenov. Squabbles inside the collective could lead to disastrous consequences for the Altai organization. Oppositionists gathered secret meetings, tried to create the party faction. Only the intervention of Sibbyuro and re-election of Committee helped to avoid a split of the Komsomol. The most active oppositionists were transferred from the Altai organization to work in other regions ${ }^{2}$.

Finally, the highest level of non-conformism was expressed in the refusal to follow the general Komsomol line some organizations. In this sense, the curious story has occurred with the Siberian 
Central Komsomol organization (Sibbyuro). To work in Siberia the Central Committee of Komsomol and the Central Committee of the Bolshevik party have decided to create a coordinating body - Sibbyuro. For these purposes from Perm and Moscow were sent Yutt F., Mavrin I., Milchakov A. and 9 other people in the beginning of 1920. Apparently, with decision were not consented some representatives of the local Komsomol movement, in particular, the leaders of the Omsk provincial organization. The position of confrontation was not reflected in the official report, however, in the memoirs Milchakov said: «Sibbyuro which was sent to Omsk from Moscow did not want to recognize on place, and many have expressed objections to the appointment, it was terrible» (Gody Nashi..., 1958: 15). This idea is confirmed by the fact that some time Omsk provincial Committee refused to work with Sibbyuro: did not send reports and communicated directly with the Central Committee of the Komsomol. The Siberian Central Komsomol organization was forced to appeal to the Central Committee of the youth League with a statement about the disobedience a number of organizations and the proposals for further work in November 1920. The Central Committee was declared in the message the culprit of the current situation. Sibbyuro called abnormal when all communication and leadership by Komsomol organizations of Siberia were carried out through the provincial departments. And warned about the possible development of «oblastnichestvo» ${ }^{3}-$ a political movement directed on formation of autonomous Siberian polity, which was originated in the mid-19th century and reached a high during the Russian Civil War.

Disappointment and sometimes hatred to communistic ideology led to attempts of youth consolidation on other principles. Supervision was established for each emerging youth organization. Analysis on secret documents of the local departments of the Joint State Political Directorate (OGPU - Obyedinyonnoye gosudarstvennoye politicheskoye upravleniye), Komsomol correspondence, periodicals allowed us to single out the main types of alternative youth associations. Firstly, it were cultural clubs, circles, and the unions which were carrying out educational functions. Cultural and educational clubs existed in many Siberian villages. Their organizers were the local intelligentsia against which Bolsheviks took a position of confrontation. Komsomol attempted to turn such clubs into communist organizations. But not always organized propaganda campaign had an amazing success, and not all clubs sought to be a part of Komsomol. In such cases, the young Communists requested the party assistance, demanded to ban the club work, disband it and transfer all property in the youth union. Serious fight was developed between the working and studying youth in Omsk. Political activity was recognized wrong by pupils, they suggested concentrating the main attention on education. As a result on one of meetings after the performance Bolshevik Blusevich the studying youth in protest left a hall and the organization (Eto nasha..., 1988: 13-14).

Secondly, it were political opponents of Bolsheviks: Socialist-revolutionaries, Mensheviks, anarchists leading anti-Communist propaganda and agitation. So, the socialist union of youth has been formed under the leadership of the head of local school Korolinsky and clerk Serebrenikov in the village Yama of Altai province in 1924. This union had included the majority of youth local Komsomol organization, and because of that it broke up soon ${ }^{4}$. This case allowed us to make a conclusion about active anticommunistic propaganda by members of the new union. In the early 1920's in Siberia except socialists were Mensheviks and anarchists youth unions and unions of students (Shtyrbul, 2008: 479). 
Thirdly, it were associations on religious (Muslim, evangelistic, Baptist, etc.) or a national basis (Latvian, Jewish, German unions), acting often as the independent organizations. Youth unions existed on a religious basis in majority of Siberian districts (Sovetskaja vlast', 2004). For example, anticommunistic Tatar union worked in the Zalari village of Irkutsk district ${ }^{5}$. The conquest the national youth was the primary task for the Komsomol. The Komsomol Committee of Omsk province wrote in a letter in the beginning of 1922: «if in relation to cultural and educational clubs we must act in different ways, against the Christian youth unions our principal task is to wrest young people out of these organizations ${ }^{6}$.

From the first days the Komsomol fiercely combated against the political competitors. The unions of youth standing on other ideological platform were abolished. Sports, cultural, educational and scout clubs were liquidated. «In relation to other political organizations (of youth R. V.), - pointed out the Plenum of the Komsomol in April 1919, - it is necessary to be guided by the relations which are at the Communist party» (Bahareva, Lejkin, 1990: 103). In the conditions of class lines youth demonstrated readiness to a force solution socio-political and interpersonal conflicts, intolerance to opponents and aggression in relation to imaginary enemies that often led to tragic consequences. The illegal acts of youth with application of violence were typical both for Komsomol members and for their opponents.

The archival documents contain enough examples demonstrating aggression of young people to ideological opponents. Primarily it affected people believing in God. Komsomol members were fierce fighters with the Church and with the parishioners. It was hard for those who recently left the organization, showed cowardice and political unreliability. Komsomol leaders tried to overcome such acts of youth. The problem was discussed at congresses, plenary sessions and meetings.

On the other hand there was population hostility to Komsomol members and communists. Intimidation and murders of Komsomol members, attacks on reading rooms, clubs, disruption of various political and cultural campaigns were the examples of anti-soviet hooliganism in Siberia. Furthermore, the militant character of the Komsomol's antireligious campaigns during the 1920s provoked the open hostility of the older rural generation towards the organization. Parents often refused to allow their offspring to join the youth league which led some youngsters to break off ties with their families (Neumann, 2012: 287).

\section{Conclusion}

Thus youth movement within the 1920th years developed under the influence of political, economic and social factors. Soviet modernization had been the engine of rapidly growing youth activity. Youngsters began to play a crucial role in the process of creating a new soviet society, but contradictions of the soviet period were reflected in Komsomol too. For example, they were appeared in formation of non-conformist views and in increasing violence. On the other side, there were another youth organizations besides the Komsomol in the early 1920s which claimed independence and opposed communistic system. Their studying is the problem of modern historical researches.

\footnotetext{
Gosudarstvennyi arhiv Novosibirskoi oblasti [The state archive of Novosibirsk region - then GANO]. F. P-187. Op. 1. D. 204. L. 1-8.

GANO F. P-187. Op. 1. D. 118. L. 290-291.

3 Gosudarstvennyi istoricheskii arhiv Omskoi oblasti [The State historical archive of Omsk region - then GIAOO] F. 36. Op. 1. D. 14. L. 5.

4 GANO F. P-188. Op. 1. D. 10. L. 1.
} 


\section{References}

1. Bahareva A. N. Lejkin Ia. A. Komsomol - aktivnyi pomoshhnik RKP(b) v bor'be $s$ neproletarskimi partiiami i soiuzami za molodezh' (1917-1925) [Komsomol - the active assistant to RKP(b) in fight against not proletarian parties and the unions for youth (1917-1925)]. Istoricheskii opyt bor'by KPSS s neproletarskimi partiiami, gruppami i techeniiami za molodezh' (1903-seredina 20-h godov), (Historical experience of fight against not proletarian parties, groups and currents for youth (1903 - the middle of the 20th years). Leningrad, 1990, pp. 98-106.

2. Davletchina S. B. Slovar' po konfliktologii [Dictionary on conflictology]. Ulan-Ude, 2005. $100 \mathrm{p}$.

3. Gody Nashi Komsomol'skie: iz vospominanii omskih komsomol'cev dvadcatyh godov [Our Komsomol years: from memoirs of Omsk Komsomol members of the twentieth years]. Omsk, 1958. 66(7) p.

4. Isaev V. I. Molodezh' Sibiri v transformiruiushhemsia obshhestve: usloviia i mehanizmy socializacii (1920-1930-e gg.) [Youth of Siberia in transformed society: conditions and socialization mechanisms (1920-1930)]. Novosibirsk, 2003. 242 p.

5. Isaev V. I. (2002). Voenizacija molodezhi i molodezhnyj jekstremizm v Sibiri (1920-e nachalo 1930-h gg.) [Militarization of youth and youth extremism in Siberia (1920th - the beginning of the 1930th )]. Vestnik NGU. Serija: Istorija, filologija. (1)3. Novosibirsk, pp. 63-70.

6. Eto nasha s toboi biografiia. Omskii komsomol. Hronika. Dokumenty. Vospominaniia. Ocherki [This is our biography. Omsk Komsomol. Chronicle. Documents. Memories. Essays. Omsk]. Omsk, 1988. 365 p.

7. Kenez P. The Birth of the Propaganda State: Soviet Methods of Mass Mobilization, 1917-1929. Cambridge, 1985. 308 p.

8. Nash kraj. Tara. 1921, 8 March.

9. Neumann M. (2012) "Youth, It's Your Turn!": Generations and the Fate of the Russian Revolution (1917-1932). Journal of Social History. 46(2), pp. 273-304.doi:10.1093/jsh/shs098

10. Neumann M. The Communist Youth League and the Transformation of the Soviet Union, 1917-1932. London, 2011. $289 \mathrm{p}$.

11. Shtyrbul A. A. Politicheskaia kul'tura Sibiri: opyt provincial'noi mnogopartiinosti (konec $X I X$-pervaia tret' $X X$ v.) [Political culture of Siberia: experience of provincial multi-party system (the end of XIX - the first third of the XX century)]. Omsk, 2008. $612 \mathrm{p}$.

12. Slesin A. A. Molodezh'i vlast'. Iz istorii molodezhnogo dvizhenia v Tsentral 'nom Chernozem'e, 1921-1929 [Youth and power: from history of youth movement in the Central Chernozem region, 19211919]. Tambov, 2002. $220 \mathrm{p}$.

13. Sovetskaia vlast' i evangel'skie cerkvi Sibiri v 1920 - 1941 gg. Dokumenty i materialy [The Soviet power and evangelical churches of Siberia in 1920 - 1941. Documents and materials.]. Novosibirsk, 2004. 427 p. 


\section{Молодежный нонконформизм в 1920-е годы: \\ основные типы и формы проявления}

\section{P.В. Рыбаков}

Омский государственный технический университет Россия, 644050, Омск, пр. Мира, 11

Статья посвящена исследованию молодежи 1920-х годов с использованием теории нонконформизма. По мнению автора, молодежное движение исследуемого периода было более сложным, чем представляла советская историография. Особенностью молодежного движения в первые годы Советской власти был рост протестных настроений, или нонконформизма. Автор охарактеризовал главные формы и типы нонконформизма среди подрастающего поколения. Их анализ значительно обогащает имеющиеся знания о молодежи 1920-х годов.

Ключевые слова: молодежь, молодежная политика, молодежные организации, комсомол, молодежный нонконформизм, национальные меньшинства, оппозииия, модернизация.

Работа выполнена при поддержке РФФИ проект № 15-06-05864а.

Научная специальность: 07.00.00 - исторические науки. 